\title{
Inhibitory effects of Tunisian plants extracts on oxidative stress and lipid accumulation in HepG2 cells
}

\author{
SukJin Kim, Gun-Hee Kim* \\ Department of Bio-Health Convergence Major, Duksung Women's University, Seoul 01369, Korea
}

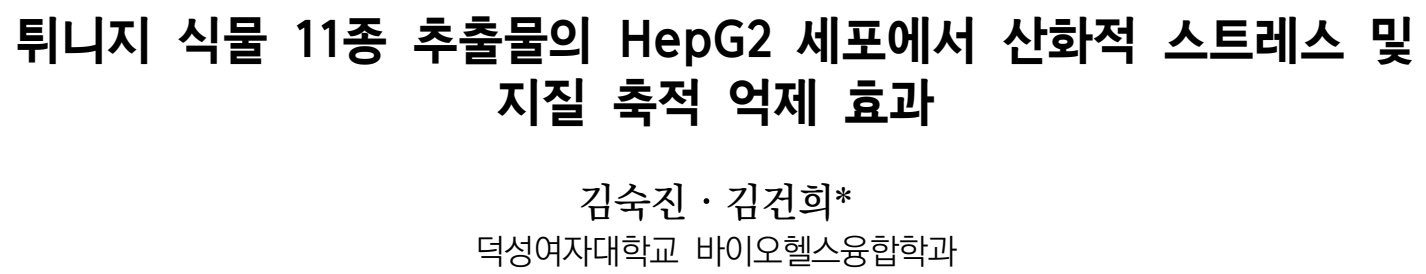

\begin{abstract}
This study was undertaken to evaluate the antioxidative and lipid accumulation inhibitory effects in HepG2 cell of 11 Tunisian plants extracts. Total phenolics contents (TPC), and total flavonoid contents (TFC) of 11 plants extracts were measured, and antioxidative activities was analyzed using DPPH, ABTS, FRAP, ORAC and TBA assay. Inhibitory effect of oxidative stress was evaluated by cell viability and lipid peroxidation level in $\mathrm{H}_{2} \mathrm{O}_{2}$-treated HepG2 cells. Lipid accumulation inhibitory effect was determined by Oil-Red-O staining and intracellular triglyceride assay in HepG2 cell. M. communis L. (156.73 mgGAE/g) and $N$. glauca Graham (108.81 mgNAE/g) were the highest TPC and TFC, respectively, among 11 plants. M. communis L. were the highest antioxidant activity in DPPH and ABTS. FRAP and ORAC results revealed that antioxidant activity in 10 species were higher than the positive control. Among the 11 species, 5 species with the lowest malondialdehyde level were selected and HPLC analysis revealed that plants contain caffeic acid, quercetin, and rutin. 5 plants treatment inhibited lipid peroxidation level and protected HepG2 cells from oxidative stress. Moreover 5 plants significantly inhibited the lipid accumulation and triglyceride content. These results imply scientific evidence for the development of functional foods using 11 plants from Tunisia which has oxidative stress and lipid accumulation reduction effects.
\end{abstract}

Key words : Tunisia, hepatoprotective effects, oxidative stress, lipid accumulation, HepG2

\section{서 론}

활성산소종(reactive oxygen species, ROS)은 체내의 효소 반응 및 미토콘드리아 호흡과정에서 부산물로 생성되며, 매 우 불안정하여 안정성을 가지기 위해 DNA, 단백질 및 지방 등과 반응한다 $(\mathrm{Li}$ 등, 2016). 적절한 활성산소는 호르몬 생산, 정상적인 세포 기능과 신호 전달 및 체내 감염된 세균을 파괴 할 때 필요하지만, 활성산소의 과도한 축적은 DNA와 단백질
손상, 염증, 노화, 퇴행성 뇌 질환, 혈관계 질환 등 많은 질병 에 관여한다(Brieger 등, 2012; Lam 등, 2020). 따라서 반응성 이 매우 큰 활성 산소인 superoxide anion $\left(\cdot \mathrm{O}_{2}{ }^{-}\right)$, hydrogen peroxide $\left(\mathrm{H}_{2} \mathrm{O}_{2}\right)$, hydroxyl ion $\left(\mathrm{OH}^{-}\right)$및 singlet oxygen $\left(\mathrm{O}_{2}\right)$ 등으로부터 세포를 보호하고, 여러 질병을 예방하기 위한 식 물 유래 천연 항산화제를 통한 체내 항산화 방어 시스템 향상 이 필요하다(Lam 등, 2020).

간은 인체에서 가장 큰 장기이며, 신체에 필요한 단백질을

*Corresponding author. E-mail : ghkim@duksung.ac.kr, Phone : +82-2-901-8694, Fax : +82-2-901-8668

Received 01 January 2021; Revised 04 March 2021; Accepted 09 March 2021.

Copyright (c) The Korean Society of Food Preservation.

This is an Open Access article distributed under the terms of the Creative Commons Attribution Non-Commercial License (http://creativecommons.org/licenses/by-nc/4.0) which permits unrestricted non-commercial use, distribution, and reproduction in any medium, provided the original work is properly cited. 
제조하고 에너지를 축적하며, 신체의 저항력을 증강시켜 주 고 해독 능력이 있다(Alamri, 2018). 건강한 간은 $2.3 \%$ 의 지 방을 포함하지만 지질 과산화 및 cytokine으로 인해 hydroxyl radical과 같은 산화스트레스를 생산하여 비알코올성 지방간 염을 유발한다(Stefan 등, 2019). 또한 산화스트레스에 의한 간 독성이 유발되면 간조직의 섬유화, 간암 등의 다양한 간 기능 장애와 질병을 일으킨다(Masarone 등, 2018). 최근 연 구에 따르면 폴리페놀 및 플라보노이드의 항산화 효과에 의 한 간 효소 수치의 호전뿐 아니라, 간세포에서 지질 축적 억 제, 비알코올성 지방 간염의 조직학적 호전 및 섬유화의 호전 이 보고된 바 있다(Guan과 He, 2015) 따라서 항산화 효과를 통한 간 보호 효과 및 지질 축적률을 감소시키는 것은 효율적 인 기전으로 연구되고 있다.

북아프리카 국가인 튀니지는 지중해 북부 기후대, 중앙 대 초원 기후대 및 남부 사막 기후대와 같이 세 가지 주요 기후 대로 나눌 수 있다. 이러한 환경적 다양성 때문에 튀니지에는 독특한 초목과 다양한 식물이 서식한다(You 등, 2016). 천연 물은 주어진 환경과 지역에 따라 그 종이 다르며, 고유한 생 리활성 물질을 갖고 있어 천연물로부터 의약품, 식품, 화장품 등 기능성 물질 이용에 대한 연구가 가중되고 있다. 과도한 방목, 삼림 벌채, 사막화와 같은 인위적 관행으로 인한 다양한 환경 문제에 직면해 천연자원의 보호 및 이용에 대한 연구의 필요성이 대두되고 있다(Gamoun 등, 2018; Vergara 등, 2019). WHO의 2015년도 Biodiversity and health 보고에 따르면 세 계 생물자원은 약 175 만 종, 국내 생물자원은 약 3 만 종으로 우리나라는 생물자원 빈국으로 산업 활성화 기반 형성이 어렵 다. 보고에 따르면 최근 생물소재 중요성 부각에 따른 생물자 원 보호 강화와 보호를 위한 여러 국제협약(Convention on Biological Diversity, Access to genetic resources and Benefit-Sharing 등) 발효로 생물소재 접근 및 공동 활용이 증 가하고 있다. 따라서 본 논문에서는 튀니지의 해외자원을 활 용하고자 하였다.

튀니지 식물 중 재배학적 연구가 발달하여 종의 유지에 문제 가 없으며, 앞으로 기능성 소재로 개발 가능성이 높은 11 종을 선정하였다. 특히 R. officinalis L.과 Eucalyptus 종은 종자 번 식이 용이하여 재배작물화 되었으며, Eucalyptus와 A. arenaria Link는 사구 안정화 식물로 토지 황폐화와 사막화를 방지한다 고 보고되었다(Bayle, 2019; Mulas와 Mulas, 2005; RodriguezEcheverria 등, 2008). L. nobilis L.는 $O$-glycosides, one flavonoid $C$-glycoside, catechin 및 cinnamtannin B1 등 10 개 이상의 플라보노이드 성분을 함유하여 위 질환에 효과적이 며, M. communis L.는 oenothein B 및 eugeniflorin 등의 폴 리페놀 성분을 통한 항진균 및 항암 효과가 뛰어나다고 보고 되었다(Dall'Acqua 등, 2009; Franco 등, 2019). 생리학적 기
능성에 대한 연구가 적은 튀니지 식물 11종을 선별하여 실험 에 사용하였다.

따라서 본 연구에서는 튀니지 식물 11종에 대하여 폴리페 놀 및 플라보노이드 함량과 이에 따른 항산화 활성을 분석하 였다. 지질 과산화물 억제 효과가 좋은 종을 선별하고, HepG2 세포에서의 산화스트레스에 의한 세포 보호 효과 및 지질 축 적률 억제 효과를 검증하였다. 본 논문은 튀니지 식물 11종의 천연물 활용을 위한 기초 자료로 제공하고자 연구를 수행하 였다.

\section{연구 내용 및 방법}

\section{실험재료}

실험에 사용된 1,1-diphenyl-2-picrylhydrazyl(DPPH), 2,2'azobis(2-amidinopropane)dihydrochloride(AAPH), 2,2'-azinobis(3-ethylbenzothiazoline-6-sulfonic acid(ABTS), 3-(4,5dimethylthiazol-2-yl)-2,5-dimethyltetrazolium bromide(MTT), dimethyl sulfoxide(DMSO) 및 phosphate buffered saline(PBS) 등 그 외 모든 시약은 Sigma-Aldrich(St. Louis, MO, USA)로 부터 구입하였다. 세포 배양 시 사용하는 fetal bovine serum (FBS) 및 Dulbecco's modified Eagle's medium(DMEM) 배지 는 Welgene(Welgene, Daegu, Korea)에서 구입하였다.

\section{식물 추출물}

본 실험에 사용된 튀니지 식물 추출물 11 종은 해외생물소 재센터(IBMRC; International Biological Material Research Center, Daejeon, Korea)로부터 분양받아 사용하였으며, Table 1 에 제시하였다. 제공받은 11 종의 식물 추출물들은 100 $\mathrm{mg} / \mathrm{mL}$ 의 농도로 $\mathrm{DMSO}$ 에 용해하여 stock한 뒤, $-70^{\circ} \mathrm{C}$ 에 보 관하며 실험에 사용하였다.

\section{총폴리페놀 및 총플라보노이드 함량 측정}

총폴리페놀 함량은 Stratil 등(2006)의 방법을 변형하여 측 정하였다. 시료 $50 \mu \mathrm{L}$ 와 Folin-Ciocalteu's phenol reagent 50 $\mu \mathrm{L}$ 를 실온에서 3 분간 반응시켰다. 반응액에 $2 \%$ sodium carbonate $\left(\mathrm{Na}_{2} \mathrm{CO}_{3}\right)$ 용액 $150 \mu \mathrm{L}$ 를 첨가하여 암실에서 2시간 동안 반응시킨 후 상등액을 ELISA plate reader(Model 680, Bio-Rad La-boratories, Inc., Tokyo, Japan)를 사용하여 760 $\mathrm{nm}$ 에서 흡광도를 측정하였다. Gallic acid equivalent(GAE) 를 표준물질로 한 검량 곡선으로 시료의 총폴리페놀 함량을 정량하였다.

총플라보노이드 함량은 Gurnani 등(2016)의 방법에 따라 시료 $20 \mu \mathrm{L}$, diethylene glycol $200 \mu \mathrm{L}$ 와 $1 \mathrm{~N} \mathrm{NaOH} 20 \mu \mathrm{L}$ 를 첨가하여 $37^{\circ} \mathrm{C}, 1$ 시간 반응시켰다. 반응액의 흡광도를 420 
Table 1. Contents of total polyphenols and total flavonoids in 11 Tunisian plants extracts

\begin{tabular}{|c|c|c|c|}
\hline \multicolumn{2}{|r|}{ Sample } & \multirow{2}{*}{$\begin{array}{l}\text { Total polyphenols } \\
\text { (mgGAE/g) }\end{array}$} & \multirow{2}{*}{$\begin{array}{l}\text { Total flavonoids } \\
\text { (mgNAE/g) }\end{array}$} \\
\hline Sample NO. & Species & & \\
\hline 1 & Ammophila arenaria Link & $9.40 \pm 0.87^{\mathrm{i} 1)}$ & $10.63 \pm 3.30^{\mathrm{g}}$ \\
\hline 2 & Callistemon citrinus Skeels & $127.33 \pm 3.36^{\mathrm{c}}$ & $57.14 \pm 6.68^{\text {cde }}$ \\
\hline 3 & Cistus villosus $\mathrm{L}$. & $135.97 \pm 3.98^{\mathrm{b}}$ & $48.73 \pm 3.47^{\mathrm{def}}$ \\
\hline 4 & Eucalyptus camaldulenis Dehnh. & $122.98 \pm 4.52^{\mathrm{c}}$ & $44.29 \pm 5.38^{\mathrm{f}}$ \\
\hline 5 & Eucalyptus gomphocephala DC. & $83.10 \pm 1.44^{\mathrm{d}}$ & $54.44 \pm 1.82^{\text {cdef }}$ \\
\hline 6 & Laurus nobilis L. & $44.07 \pm 1.85^{\mathrm{f}}$ & $60.56 \pm 3.45^{\mathrm{c}}$ \\
\hline 7 & Myrtus communis L. & $156.73 \pm 3.96^{\mathrm{a}}$ & $49.05 \pm 4.56^{\mathrm{def}}$ \\
\hline 8 & Nicotiana glauca Graham & $38.85 \pm 1.56^{\mathrm{h}}$ & $108.81 \pm 12.38^{\mathrm{a}}$ \\
\hline 9 & Pistacia lentiscus L. & $156.0 \pm 2.50^{\mathrm{a}}$ & $48.10 \pm 4.65^{\mathrm{ef}}$ \\
\hline 10 & Rosmarinus officinalis L. & $40.82 \pm 1.62^{\mathrm{fg}}$ & $89.20 \pm 5.27^{\mathrm{b}}$ \\
\hline 11 & Thymus capitatus Hoffmanns. \& Link & $57.67 \pm 1.98^{\mathrm{e}}$ & $59.60 \pm 7.12^{\mathrm{cd}}$ \\
\hline
\end{tabular}

\footnotetext{
${ }^{1)}$ All values represent mean \pm SD $(n=3)$. Values with different letters are significantly different by Duncan's multiple range test ( $\mathrm{p}<0.05$ ).
}

$\mathrm{nm}$ 에서 측정하였으며, naringin equivalent(NAE)를 표준물 질로 한 검량 곡선으로 시료의 총플라보노이드 함량을 정량 하였다.

\section{$\mathrm{DPPH}$ radical 소거능 측정}

튀니지 식물 11종의 DPPH radical 소거능 측정은 Wahyono 등(2020)의 방법을 활용하였다. 각 추출물을 농도별 $(0.05$, $0.1,0.5,1.0$ 및 $2.0 \mathrm{mg} / \mathrm{mL}$ )로 희석한 시료 $50 \mu \mathrm{L}$ 와 $0.3 \mathrm{mM}$ $\mathrm{DPPH} 150 \mu \mathrm{L}$ 를 실온에서 30 분간 반응시키고, $517 \mathrm{~nm}$ 에서 흡광도 값을 측정하였다. Ascorbic acid를 양성대조군으로 사 용하였으며, 시료 무첨가구에 대한 첨가구의 값을 비교하여 DPPH radical 소거활성을 결정하였다. 결과값은 free radical 소거 활성이 $50 \%$ 인 추출물의 $\mathrm{IC}_{50}(\mathrm{mg} / \mathrm{mL})$ 로 나타냈다.

\section{ABTS radical 소거능 측정}

ABTS radical 소거능 측정은 Wahyono 등(2020)의 방법을 변형하여 측정하였다. $7.4 \mathrm{mM} \mathrm{ABTS}$ 와 $2.6 \mathrm{mM}$ potassium persulfate를 혼합하고, 암실에서 24시간 반응시킨 후, $734 \mathrm{~nm}$ 에서 흡광도가 $0.7 \pm 0.002$ 가 되도록 PBS으로 희석하여 $\mathrm{ABTS}$ solution을 사용하였다. $0.05,0.1,0.5,1.0$ 및 $2.0 \mathrm{mg} / \mathrm{mL}$ 농 도의 $20 \mu \mathrm{L}$ 시료에 $180 \mu \mathrm{L} \mathrm{ABTS} \mathrm{solution을} \mathrm{첨가하여} 10$ 분 간 암소에서 반응시킨 후 흡광도를 $732 \mathrm{~nm}$ 에서 측정하였다. Ascorbic acid를 양성대조군으로 이용하였으며, 결과값은 $\mathrm{IC}_{50}(\mathrm{mg} / \mathrm{mL})$ 값으로 나타냈다.

\section{FRAP assay}

FRAP법에 의한 항산화 활성은 Wahyono 등(2020)의 방법 에 따라 $0.3 \mathrm{mM}$ sodium acetate buffer(pH 3.6), $40 \mathrm{mM} \mathrm{HCl}$ 에 용해한 $10 \mathrm{mM} \mathrm{2,4,6-tripyridyl-s-triazine(TPTZ)} \mathrm{용액} \mathrm{및}$ $20 \mathrm{mM}$ ferric chloride를 각각 10:1:1(v/v/v)의 비율로 혼합하 여 FRAP 기질액으로 사용하였다(Vijalakshm과 Ruckmani, 2016). 96-well plate에 $0.1 \mathrm{mg} / \mathrm{mL}$ 농도의 시료 $50 \mu \mathrm{L}$ 와 FRAP 기질액 $150 \mu \mathrm{L}$ 를 혼합하여 암소에서 20 분간 반응 후 흡광도를 $593 \mathrm{~nm}$ 에서 측정하였다. Ferrous sulfate를 표준 물 질로 한 표준 검량선으로부터 정량하였으며, ascorbic acid를 양성대조군으로 사용하였다.

\section{ORAC assay}

튀니지 식물 추출물의 oxygen radical absorbance capacity (ORAC) 측정은 Wahyono 등(2020)의 방법을 변형하여 사용 하였다. $0.1 \mathrm{mg} / \mathrm{mL}$ 농도의 시료, 표준 물질 또는 양성대조군 $25 \mu \mathrm{L}$ 와 $40 \mathrm{nM}$ fluorescein $150 \mu \mathrm{L}$ 를 $37^{\circ} \mathrm{C}$ 에서 10 분간 반응 시켰다. 반응 용액에 $150 \mathrm{mM} \mathrm{AAPH} 25 \mu \mathrm{L}$ 를 첨가한 뒤 형 광 광도계(Tecan Infinite M200, San Jose, CA, USA)를 이용 하여 90 분 동안 3 분 간격으로 측정하였다. 형광 광도계의 excitation(485 nm)과 emission(520 nm)을 설정하여 측정하 였다. 결과 값은 시료 무첨가구에 대한 첨가구의 area under curve(AUC) 값을 구한 후, trolox equivalent(TE)를 표준물질 로 한 표준 검량 곡선에 대입하여 정량하였다. 


\section{TBA assay}

튀니지 식물 추출물의 지질 과산화물 측정은 thiobarbituric acid(TBA) assay를 변형하여 사용하였다(Dissanayake 등, 2009). $0.1 \mathrm{mg} / \mathrm{mL}$ 시료에 $10 \mathrm{mM}$ linolenic acid를 혼합 후 $37^{\circ} \mathrm{C}$ 에서 1시간 반응시켰다. 반응 후 $0.05 \mathrm{M} \mathrm{H}_{2} \mathrm{O}_{2}$ 와 $\mathrm{FeSO}_{4}$ 를 첨가하고, $37^{\circ} \mathrm{C}$ 에서 2 시간 반응시킨 후, $0.4 \% \mathrm{TBA}$ 를 첨가 하여 $95^{\circ} \mathrm{C}$ water bath에서 15 분간 반응시켰다. 그 후 butanol $500 \mu \mathrm{L}$ 를 첨가하여 $1,000 \times g$ 로 10 분 원심분리 후 상등액의 흡광도를 $532 \mathrm{~nm}$ 에서 측정하였다. 지질 과산화 억제능은 표 준물질인 malondialdehyde(MDA)를 이용하여 정량하고, 양 성대조군은 quercetin을 이용하였다.

\section{$\mathrm{HPLC}$ 분석}

튀니지 식물에 함유된 caffeic acid, quercetin 및 rutin를 확 인하기 위하여 HPLC 분석을 실시했으며, 두 개의 표준물질 을 동시에 분석하기 위하여 Thermo Scientific ${ }^{\mathrm{TM}}$ UltiMate $^{\mathrm{TM}}$ 3000 UHPLC Systems(Waltham, MA, USA)과 Agilent column $(5 \mu \mathrm{m}, 4.6 \times 250 \mu \mathrm{mm}$, Santa Clara, CA, USA)을 이용 하였다(Bianchin 등, 2020). 칼럼 온도는 $25^{\circ} \mathrm{C}$, 유속은 1.0 $\mathrm{mL} / \mathrm{min}$ 및 시료 주입량은 $20 \mu \mathrm{L}$ 로 유지하였다. $\mathrm{HPLC}$ 이동상 은 A: $1 \%$ acetic acid, B: $100 \%$ methanol 두 용액계를 사용하 였다. 기울기 용매조건은 다음과 같았다: 0-2 $\min \mathrm{B}(5-10 \%)$, 2-3 min $\mathrm{B}(10-12 \%)$, 3-5 min $\mathrm{B}(12-16 \%), 5-10 \min \mathrm{B}(16-23 \%)$, 10-20 min $\mathrm{B}(23-33 \%), 20-30$ min $\mathrm{B}(33-45 \%)$, 30-40 min $\mathrm{B}(45-65 \%), 40-45 \min \mathrm{B}(65-80 \%), 45-50 \min \mathrm{B}(80-100 \%)$, $50-55 \min \mathrm{B}(100 \%)$, 55-60 $\min \mathrm{B}(100-5 \%)$, 60-65 min $\mathrm{B}(5 \%)$. 검출파장은 $285 \mathrm{~nm}, 300 \mathrm{~nm}$ 및 $325 \mathrm{~nm}$ 에서 검출하 였다. 시료는 표준 물질인 caffeic $\operatorname{acid}\left(\mathrm{y}=0.212 \mathrm{x}, \mathrm{R}^{2}=0.999\right)$, quercetin $\left(\mathrm{y}=0.4457 \mathrm{x}, \mathrm{R}^{2}=0.992\right)$, rutin $\left(\mathrm{y}=0.2379 \mathrm{x}, \mathrm{R}^{2}=0.994\right)$ 로 정량하였다.

\section{HepG2 세포 배양}

인간 간암 세포주 human hepatocellular carcinoma cell line(HepG2) 세포는 한국세포주은행에서 분양받아 사용하였 으며, $10 \% \mathrm{FBS}, 1 \%$ Anti-biotic Anti-mycotic을 포함한 $\mathrm{DMEM}$ 배지를 사용하여, $37^{\circ} \mathrm{C}, 5 \% \mathrm{CO}_{2}$ 조건에서 배양하였 다(Um과 Kim, 2016). 세포는 2일마다 계대 배양하여 적정 수의 세포를 유지하였다.

\section{MTT assay}

HepG2 세포에 대한 튀니지 식물의 세포 내 독성 및 산화 적 스트레스에 의한 세포 보호 효과를 확인하기 위하여 MTT assay를 이용해 세포 생존율을 측정하였다(Youn 등, 2015). HepG2 세포를 96-well plate에 $1 \times 10^{5}$ cells $/ \mathrm{mL}$ 분주하고, $37^{\circ} \mathrm{C}$,
$5 \% \mathrm{CO}_{2}$ 조건에서 24 시간 배양 후, 시료 $(0.1,0.2$ 및 0.4 $\mathrm{mg} / \mathrm{mL}$ ) 및 $100 \mu \mathrm{M} \mathrm{H}_{2} \mathrm{O}_{2}$ 를 첨가하였다. 24시간 배양 후 PBS에 녹인 MTT $(5 \mathrm{mg} / \mathrm{mL})$ 용액을 각 $20 \mu \mathrm{L} / \mathrm{well}$ 씩 처리한 후, 4 시간 배양하였다. 이후 생성된 formazan 결정을 용해하 기 위해 상등액을 제거하고, $\mathrm{DMSO}$ 를 $100 \mu \mathrm{L} / \mathrm{well}$ 에 첨가하 여 $540 \mathrm{~nm}$ 에서 흡광도를 측정하였다. 세포 생존율은 다음 식 으로 산출하였다.

Cell viability $(\%)=\mathrm{B} / \mathrm{A} \times 100$
A: control의 흡광도
$\mathrm{B}$ : 시료 처리 세포의 흡광도

\section{Lipid peroxidation 측정}

튀니지 식물이 HepG2 세포의 지질 과산화물 생성 억제 효 과를 확인하기 위하여 Youn 등(2015)의 방법을 변형하여 사 용하였다. $1 \times 10^{6}$ cells $/ \mathrm{mL}$ 의 HepG2 세포를 6-well plate에 분주하고 24시간 후, $0.2 \mathrm{mg} / \mathrm{mL}$ 시료, $1 \mathrm{mM} \mathrm{H}_{2} \mathrm{O}_{2}$ 및 $1 \mathrm{mM}$ $\mathrm{FeSO}_{4}$ 를 혼합하여 24시간 배양시켰다. 산화스트레스가 유도 된 HepG2 세포는 PBS로 3회 세척 후 scraper로 회수하여 $500 \mu \mathrm{L} 25 \%$ trichloroacetic acid(TCA)와 $0.67 \% \mathrm{TBA}$ 를 첨 가하여 $95^{\circ} \mathrm{C}$ 에서 30 분간 가열하였다. $15: 1$ 비율의 n-butanol: pyrimidine를 첨가하여 원심분리(13,000 rpm, $5 \mathrm{~min})$ 시킨 후 상등액을 $532 \mathrm{~nm}$ 에서 흡광도를 측정하였다.

\section{Oil-Red-O staining}

$\mathrm{HepG} 2$ 세포에서 생성된 총 지질 축적률은 Oil-Red-O (ORO) 염색을 통해 측정하였다(Ahn 등, 2015). $1 \times 10^{6}$ cells $/ \mathrm{mL}$ 의 HepG2 세포를 6-well plate에 분주하고, 24시간 후 $0.2 \mathrm{mg} / \mathrm{mL}$ 시료와 $0.6 \mathrm{mM}$ oleic acid $(\mathrm{OA})$ 를 처리하여 24시간 배양시켰다. 분화 유도된 $\mathrm{HepG} 2$ 세포의 배양액을 제 거 후 PBS로 2회 세척하였다. 세포 고정을 위해 각 well에 $3.7 \%$ formaldehyde를 넣고 15 분 후 $60 \%$ isopropanol로 3 번 세척하였다. ORO 염색약은 증류수와 6:4의 비율로 혼합 후 $0.2 \mu \mathrm{M}$ filter로 여과하여 사용하였다. ORO 용액을 첨가하여 30 분 이상 염색한 후 증류수로 3 번 세척하였다. 염색된 세포 내 지방구는 현미경으로 관찰한 후, 2-propanol을 첨가하여 $540 \mathrm{~nm}$ 에서 흡광도를 측정하였다. Quercetin를 양성대조군 으로 사용했다.

\section{Triglyceride assay}

HepG2 세포에서 생성된 중성 지방 함량은 Triglyceride-S kit(Asan Pharm. Co., Ltd., Seoul, Korea)를 이용하여 측정하 였다. $1 \times 10^{6}$ cells $/ \mathrm{mL}$ 의 $\mathrm{HepG} 2$ 세포를 6-well plate에 분주 
하여 24시간 후, $0.2 \mathrm{mg} / \mathrm{mL}$ 시료와 $0.6 \mathrm{mM} \mathrm{OA}$ 를 처리 후 24시간 배양시켰다. 분화 유도된 HepG2 세포는 PBS로 세척 하고, scraper로 회수 후 $10,000 \mathrm{rpm}$ 에서 5 분간 원심 분리하 였다. 원심 분리 후 상층액을 제거하고, pellet에 lysis buffer(Tris-EDTA buffer)를 첨가하여 $4^{\circ} \mathrm{C}, 12,000 \mathrm{rpm}$ 에서 원심 분리하였다. 회수한 상층액 $80 \mu \mathrm{L}$ 에 enzyme buffer solution $120 \mu \mathrm{L}$ 를 첨가하여 $37^{\circ} \mathrm{C}$ 에서 20 분간 반응시킨 후 $540 \mathrm{~nm}$ 에서 흡광도를 측정하였다. 양성대조군으로 quercetin 을 사용하였으며, 단백질 농도는 BCA 방법에 의해 정량하였 다(Walker, 1994).

\section{통계처리}

모든 실험은 3 회 이상 반복 실시하였으며, 통계 유의성 검증 은 SPSS program(ver. 19.0, SPSS Inc., Chicago, IL, USA) 을 이용하여 ANOVA를 실시하고, Duncan's multiple range test로 각 조사 항목 간의 유의차 검정을 $5 \%$ 수준에서 실시하 였다.

\section{결과 및 고찰}

\section{튀니지 식물의 총폴리페놀 및 총플라보노이드 함량}

튀니지 식물 추출물 11종의 총폴리페놀 및 플라보노이드 함량을 계산한 결과는 Table 1에 나타냈다. 식물체에 함유되 어 있는 페놀 화합물들은 활성산소를 제거하는 작용기작을 통해 심장질환, 당뇨, 뇌졸중 억제 등의 다양한 생리활성을 가 지는 것으로 보고되었다(Cory 등, 2018). 총폴리페놀 함량은 M. communis L.(156.73 mgGAE/g) > P. lentiscus L.(156.0 $\mathrm{mgGAE} / \mathrm{g})>$ Cistus villosus L.(135.97 $\mathrm{mgGAE} / \mathrm{g})>$ Callistemon citrinus Skeels(127.33 mgGAE/g) $>$ E. camaldulenis Dehnh (122.98 mgGAE/g) 순으로 높게 나타났다(Table 1). $M$. communis L.이 속한 M. communis종은 quercetin 3-Ogalactoside, epigallocatechin 및 myricetin 3-O-galactoside 등 많은 폴리페놀 성분을 함유하는 것으로 보고되었으며, 잎 과 열매를 메탄올, 에탄올 및 수성으로 추출한 경우 총폴리페 놀 함량이 9.0-35.6 mgGAE/g이라고 보고되었다. 이에 비해 본 논문의 튀니지 식물 11종의 총폴리페놀 함량은 평균 88.45 $\mathrm{mgGAE} / \mathrm{g}$ 으로 보고된 M. communis나 종에 비해 높은 폴리 페놀 함량을 확인하였으며, 이 성분에 따른 강력한 항산화 효 능이 나타날 것으로 추측된다(Amensour 등, 2009; Romani 등, 1999).

플라보노이드는 폴리페놀 구조를 갖는 2 차 대사산물로 폴 리페놀과 마찬가지로 항산화 효과를 지녀 세포 효소 기능 조 절, 항염증, 항암, 동맥 경화증 예방 등 광범위한 건강증진 효 능을 통해 다양한 기능성 식품, 제약 및 의약 분야의 필수 구
성요소이다(Panche 등, 2016). 식물 11종 중에서 N. glauca Graham(108.81 mg NAE/g) > R. officinalis L.(89.20 mgNAE/g) $>$ L. nobilis L.(60.56 mgNAE/g) > T. capitatus Hoffmanns \& $\operatorname{Link}(59.60 \mathrm{mgNAE} / \mathrm{g})>$ C. citrinus $\operatorname{Skeels}(57.14 \mathrm{mgNAE} / \mathrm{g})$ 순으로 총플라보노이드 함량이 높게 나타났으며, A. arenaria Link은 $10.63 \mathrm{mgNAE} / \mathrm{g}$ 으로 가장 낮은 함량을 보였다(Table 1). N. glauca Graham이 속한 N. glauca 종의 헥산 분획물 플라보노이드 함량은 $108.81 \mathrm{mg}$ quercetin $/ \mathrm{g}$ 으로 본 논문의 N. glauca Graham(108.81 mgNAE/g)과 일치하는 결과를 보 였으며, 이에 따른 높은 항산화 및 항암 효과를 지닌다고 보 고되었다(Tabana 등, 2015). 따라서 튀니지 식물 11종의 높은 폴리페놀 및 플라보노이드 함량에 따른 항산화 활성이 높을 것으로 추측된다. 튀니지 식물 11 종 중 폴리페놀 함량은 $M$. communis L., 플라보노이드 함량은 N. glauca Graham에서 제일 높게 나타났는데, 이는 폴리페놀을 구성하는 성분 중 비 플라보노이드에 속하는 ellagic acid, gallic acid, and ellagitannins 등의 다양한 구성으로 함량에 다소 차이가 있을 것으로 판단된다(Tungmunnithum 등, 2018).

\section{튀니지 식물 추출물의 항산화 활성}

$\mathrm{DPPH}, \mathrm{ABTS}, \mathrm{FRAP}$ 및 ORAC로 튀니지 식물 추출물 11 종의 항산화 활성을 측정한 결과는 Table 2에 나타냈다. DPPH 는 비교적 안정한 자유 라디칼과의 반응으로 수소나 전자를 받 아 환원될 때 보라색이 탈색되는 원리를 이용하며, 금속이온의 킬레이트화 및 효소 억제와 같은 특정 반응에 영향을 받지 않 아 안정하여 상업적으로 널리 이용되고 있는 방법이다 (Lewoyehu와 Amare, 2019). DPPH 라디칼 소거능의 $\mathrm{IC}_{50}$ 값 은 11 종 모두 $0.25 \mathrm{mg} / \mathrm{mL}$ 이하의 값을 나타냈으며, 평균 0.21 $\mathrm{mg} / \mathrm{mL}$ 로 높은 라디칼 소거능을 나타냈다(Table 2). 튀니지 식 물 11종 중 가장 높은 DPPH 라디칼 소거능을 보인 Myrtus communis $\mathrm{L}$.는 양성대조구인 ascorbic acid와 같은 $\mathrm{IC}_{50}$ 값 $0.05 \mathrm{mg} / \mathrm{mL}$ 를 나타내어 높은 항산화 효과를 확인하였다. $E$. camaldulenis Dehnh와 E. gomphocephala DC.가 속한 Eucalyptus 속의 DPPH 실험 결과, E. gillii의 hexane 추출물 $(0.82 \mathrm{mg} / \mathrm{mL})$ 및 petroleum ether 추출물 $(0.54 \mathrm{mg} / \mathrm{mL})$ 로 높은 항산화 활성을 나타냈으며, 추출 용매별로 폴리페놀 함량이 높 을수록 높은 DPPH 함량을 나타낸다고 보고되었다(Hassine 등, 2012). 본 연구의 튀니지 식물 11 종은 기존에 보고된 $E$. gillii보다 높은 항산화 활성을 나타냈으며, 폴리페놀 함량이 가 장 높았던 Myrtus communis L.종의 라디칼 소거능이 가장 높 아 폴리페놀 함량과 항산화 활성의 상관 관계를 확인하였다.

$\mathrm{ABTS}$ 라디칼 소거능은 potassium persulfate와의 반응에 의해 생성된 $\mathrm{ABTS}^{+}$가 시료 내의 항산화 물질에 의해 제거되 어 탈색되는 것을 이용한 항산화능 측정 방법이다(Lewoyehu 
Table 2. Antioxidant activities and lipid peroxidation level of 5 Tunisian plants extracts

\begin{tabular}{|c|c|c|c|c|c|}
\hline \multirow{2}{*}{ Samples } & DPPH & ABTS & \multirow{2}{*}{$\begin{array}{c}\text { FRAP } \\
\mu \mathrm{molFeSO}_{4} / \mathrm{g}\end{array}$} & \multirow{2}{*}{$\frac{\text { ORAC }}{\mathrm{mmolTE} / \mathrm{g}}$} & \multirow{2}{*}{$\frac{\text { Lipid peroxidation }}{\text { MDA (nmol/mg) }}$} \\
\hline & \multicolumn{2}{|c|}{$\mathrm{IC}_{50}(\mathrm{mg} / \mathrm{mL})$} & & & \\
\hline Ammophila arenaria Link & $0.61 \pm 0.08^{\mathrm{a} 1)}$ & $0.12 \pm 0.08^{\mathrm{a}}$ & $118.11 \pm 2.88^{\mathrm{i}}$ & $1.71 \pm 0.06^{\mathrm{f}}$ & $0.76 \pm 0.06^{\mathrm{de}}$ \\
\hline Callistemon citrinus Skeels & $0.15 \pm 0.00^{\text {ef }}$ & $0.06 \pm 0.00^{\mathrm{a}}$ & $448.14 \pm 0.75^{\mathrm{a}}$ & $3.15 \pm 0.10^{\mathrm{c}}$ & $0.83 \pm 0.01^{\text {cde }}$ \\
\hline Cistus villosus $\mathrm{L}$. & $0.14 \pm 0.00^{\mathrm{f}}$ & $0.06 \pm 0.00^{\mathrm{a}}$ & $438.91 \pm 0.36^{\mathrm{b}}$ & $2.66 \pm 0.14^{\mathrm{de}}$ & $0.76 \pm 0.03^{\mathrm{e}}$ \\
\hline Eucalyptus camaldulenis Dehnh. & $0.15 \pm 0.00^{\mathrm{ef}}$ & $0.06 \pm 0.00^{\mathrm{a}}$ & $445.47 \pm 1.41^{\mathrm{a}}$ & $3.06 \pm 0.18^{\mathrm{c}}$ & $0.91 \pm 0.08^{\mathrm{bc}}$ \\
\hline Eucalyptus gomphocephala DC. & $0.15 \pm 0.00^{\mathrm{ef}}$ & $0.09 \pm 0.00^{\mathrm{a}}$ & $426.09 \pm 0.54^{\mathrm{c}}$ & $2.74 \pm 0.08^{\mathrm{d}}$ & $0.94 \pm 0.02^{\mathrm{b}}$ \\
\hline Laurus nobilis L. & $0.19 \pm 0.01^{\mathrm{de}}$ & $0.26 \pm 0.01^{\mathrm{b}}$ & $354.59 \pm 3.26^{\mathrm{g}}$ & $2.60 \pm 0.03^{\mathrm{de}}$ & $0.97 \pm 0.02^{\mathrm{b}}$ \\
\hline Myrtus communis L. & $0.05 \pm 0.02^{\mathrm{g}}$ & $0.06 \pm 0.02^{\mathrm{ab}}$ & $428.48 \pm 3.91^{\mathrm{c}}$ & $3.99 \pm 0.11^{\mathrm{b}}$ & $1.26 \pm 0.17^{\mathrm{a}}$ \\
\hline Nicotiana glauca Graham & $0.21 \pm 0.01^{\mathrm{cd}}$ & $0.11 \pm 0.01^{\mathrm{a}}$ & $394.04 \pm 6.00^{\mathrm{e}}$ & $4.43 \pm 0.10^{\mathrm{a}}$ & $0.87 \pm 0.03^{\mathrm{bcd}}$ \\
\hline Pistacia lentiscus L. & $0.15 \pm 0.00^{\text {ef }}$ & $0.13 \pm 0.00^{\mathrm{a}}$ & $383.14 \pm 7.00^{\mathrm{f}}$ & $3.91 \pm 0.06^{\mathrm{b}}$ & $0.75 \pm 0.03^{\mathrm{e}}$ \\
\hline Rosmarinus officinalis L. & $0.25 \pm 0.00^{\mathrm{bc}}$ & $0.21 \pm 0.00^{\mathrm{a}}$ & $406.43 \pm 3.19^{d}$ & $2.53 \pm 0.13^{\mathrm{e}}$ & $0.73 \pm 0.04^{\mathrm{e}}$ \\
\hline Thymus capitatus Hoffmanns. \& Link & $0.25 \pm 0.00^{\mathrm{b}}$ & $0.14 \pm 0.00^{\mathrm{a}}$ & $409.46 \pm 2.11^{\mathrm{d}}$ & $2.55 \pm 0.10^{\mathrm{e}}$ & $0.73 \pm 0.06^{\mathrm{e}}$ \\
\hline Ascorbic acid & $0.05 \pm 0.00^{\mathrm{g}}$ & $0.08 \pm 0.00^{\mathrm{a}}$ & $312.25 \pm 1.48^{\mathrm{h}}$ & $1.73 \pm 0.14^{\mathrm{g}}$ & $0.73 \pm 0.02^{\mathrm{e}}$ \\
\hline
\end{tabular}

${ }^{1)}$ All values represent mean \pm SD $(n=3)$. Values with different letters are significantly different by Duncan's multiple range test $(\mathrm{p}<0.05)$.

와 Amare, 2019). 튀니지 식물의 ABTS 라디칼 소거 활성의 $\mathrm{IC}_{50}$ 값은 C. citrinus Skeels, C. villosus L., E. camaldulenis Dehnh 및 M. communis L.에서 $0.06 \mathrm{mg} / \mathrm{mL}$ 로 가장 높게 나 타났으며, 11 종의 $\mathrm{IC}_{50}$ 값 평균은 $0.15 \mathrm{mg} / \mathrm{mL}$ 로 나타났다 (Table 2). 양성 대조군인 ascorbic acid의 $\mathrm{IC}_{50}$ 값은 0.08 $\mathrm{mg} / \mathrm{mL}$ 로, 11종 중 4종이 ascorbic acid보다 높은 ABTS 라디 칼 소거 활성을 나타냈다. C. villosus L.종이 속한 Cistus속의 C. salviifolius 및 C. monspeliensis $\mathrm{ABTS}$ 라디칼 소거능은 $0.26 \mathrm{mg} / \mathrm{mL}$ 로 플라보노이드 함량과 상관관계가 적다고 보 고되었다(Sayah 등, 2017). 본 논문에서도 ABTS 라디칼 소 거능과 플라보노이드 함량 간 상관관계가 나타나지 않는 것 으로 보아 ABTS 라디칼 소거능이 다양한 활성 화합물의 존 재, 다른 화합물의 시너지 효과, 폴리페놀의 항산화 효율 및 수산화기의 위치와 정도에 따라 차이가 날 수 있음을 확인하 였다.

$\mathrm{Fe}^{2+}$ 는 hydroxyl $\mathrm{radical}(\cdot \mathrm{OH})$ 과 superoxide anion $\left(\cdot \mathrm{O}^{2-}\right)$ 등의 생성을 촉진하며, 이러한 금속이온인자에 대한 chelating 활성이 높을수록 산화반응에 촉매작용을 감소시킬 수 있는 능 력을 측정하는 지표로 이용된다(Lewoyehu와 Amare, 2019). 튀니지 식물 11종의 FRAP 라디칼 소거 활성은 평균 388.44 $\mu \mathrm{molFeSO}_{4} / \mathrm{g}$ 으로 $C$. citrinus Skeels $\left(448.14 \mu \mathrm{molFeSO}_{4} / \mathrm{g}\right)>$ E. camaldulenis Dehnh $\left(445.47 \mu \mathrm{molFeSO}_{4} / \mathrm{g}\right)>C$. villosus $\mathrm{L}$. (438.91 $\mu \mathrm{molFeSO} / \mathrm{g})>$ M. communis L.(428.48 $\left.\mu \mathrm{molFeSO}_{4} / \mathrm{g}\right)$ 순으로 높게 나타났다. 11종 중 폴리페놀 및 플라보노이드 함
량이 제일 낮았던 A. arenaria $\operatorname{Link}\left(118.11 \mu \mathrm{molFeSO}_{4} / \mathrm{g}\right)$ 를 제 외한 10 종이 양성대조군인 ascorbic $\operatorname{acid}\left(312.79 \mu \mathrm{molFeSO}_{4} / \mathrm{g}\right)$ 보다 높은 항산화 활성을 나타내 금속이온에 대한 뛰어난 chelating 활성을 확인하였다. Iauk 등(2015)이 보고한 바에 따르면 T. capitatus Hoffmanns. \& Link의 메탄올 및 헥산 분획물은 각각 27.7 및 $32.7 \mu \mathrm{molFeSO}_{4} / \mathrm{g}$ 을 나타냈으며, $\mathrm{DPPH}, \mathrm{ABTS}$ 및 FRAP 실험 결과, 경향이 일치한다고 나타 났다. 본 논문의 튀니지 식물 11종의 DPPH 및 $\mathrm{ABTS}$ 결과, 라디칼 소거능이 가장 높았던 식물 상위 4종이 FRAP 활성이 높은 상위 4종으로 나타났다.

ORAC assay는 일정 시간이 지남에 따라 peroxyl radical로 유도된 산화를 측정하며, 수소 원자에 의한 chain-breaking으 로 발색되는 형광 값으로 항산화능을 정량화한다(Lewoyehu 와 Amare, 2019). 튀니지 식물 11종의 ORAC value를 측정 한 결과, M. communis L.(3.99 mmolTE $/ \mathrm{g})>$ P. lentiscus L.(3.91 mmolTE/g) $>$ C. citrinus $\operatorname{Skeels}(3.15 \mathrm{mmolTE} / \mathrm{g})>$ E. camaldulenis Dehnh(3.06 mmolTE/g) 순으로 높게 나타났 으며, 양성대조군인 ascorbic acid는 $1.75 \mathrm{mmolTE} / \mathrm{g}$ 으로 나 타났다. 보다 10종의 식물이 높은 ORAC 항산화능을 보여 $\mathrm{DPPH}$ 와 달리 시료가 장시간 반응에 의한 항산화 효과가 높 다고 판단된다. Remila 등(2015)에 따르면 P. lentiscus의 잎 과 열매를 에탄올 $95 \%$ 로 각각 추출한 결과, 플라보노이드 함 량은 각각 139.38 및 $6.28 \mathrm{mg}$ rutin/g, ORAC value는 0.059 및 $0.037 \mathrm{mmolTE} / \mathrm{g}$ 으로 나타났으며, myricetinrhamnoside, 
quercetinrutinoside 및 quercetinrhamnoside 등의 플라보노이 드 성분을 통한 항산화, 세포 보호, 항염증 및 항암 효과가 보고되었다. 추출 용매 및 부위에 따른 차이로 본 논문의 $P$. lentiscus L.은 $3.91 \mathrm{mmolTE} / \mathrm{g}$ 의 ORAC value를 나타냈으며, 튀니지 11종의 ORAC value는 평균 $3.03 \mathrm{mmolTE} / \mathrm{g}$ 으로 우 수한 항산화 효과를 확인하였다. 또한 플라보노이드 함량이 가장 높았던 N. glauca Graham의 ORAC value가 가장 높아 그 상관관계를 확인하였으며, 이에 따른 항산화 활성과 세포 보호 효과 등이 나타날 것으로 추측된다. 본 논문의 DPPH, ABTS, FRAP 및 ORAC assay 실험결과, 튀니지 식물 11종 의 우수한 항산화 활성을 확인하였다.

\section{튀니지 식물 추출물의 지질 과산화물 함량 억제 활성}

미토콘드리아 ROS의 증가는 지질 과산화물 함량을 증가시 켜 더 많은 반응성 알데히드를 방출하여 미토콘드리아 DNA (mtDNA)와 호흡 전자전달계 상의 폴리펩티드를 더욱 손상 시킨다(Park 등, 2009). 지질 과산화의 최종 산물인 malonidaldehyde는 염증반응을 유발하고, 중성구를 끌어들여 염증성 cytokine 생산 유도 및 성상세포 활성화로 간섬유화를 일으킨 다. 따라서 간세포 손상을 유발하며, 비알코올성 지방간 형성 을 증가시킨다. 이에, 본실험에서는 시료의 지질과 산화물 함 량을 linoleic acid를 이용한 TBA 방법으로 MDA값에 정량하 여 Table 2에 나타냈으며, free radical을 제거하고 glutathione 감소에 의한 지질 과산화 반응을 억제한다고 보고된 quercetin 을 양성대조군으로 사용하였다(Kumar 등, 2003). 그 결과, $P$. lentiscus $\mathrm{L} .(0.73 \mathrm{nmol} / \mathrm{mg})<T$. capitatus Hoffmanns. \& Link $(0.73 \mathrm{nmol} / \mathrm{mg})<R$. officinalis L. $(0.75 \mathrm{nmol} / \mathrm{mg})<C$. villosus $\mathrm{L} .(0.76 \mathrm{nmol} / \mathrm{mg})<$ A. arenaria $\operatorname{Link}(0.76 \mathrm{nmol} / \mathrm{mg})$ 순으로 낮은 지질 과산화물 함량을 보였으며, 11 종 평균 0.86 $\mathrm{nmol} / \mathrm{mg}$ 으로 나타났다. 양성대조군으로 쓰인 quercetin의 지 질 과산화물 함량은 $0.73 \mathrm{nmol} / \mathrm{mg}$ 으로, quercetin과 지질 과
산화물 함량이 유의적으로 차이가 나지 않는 상위 5 종을 선 정하여 $\mathrm{HepG} 2$ 세포에서의 지질 축적률 및 지질 과산화물 억 제 활성을 측정하였다. 한편, 본 연구에서 가장 높은 폴리페 놀 함량을 나타냈던 M. communis L.의 지질 과산화물 함량 이 가장 낮을 것으로 예상했지만, $1.26 \mathrm{nmol} / \mathrm{mg}$ 으로 가장 높 은 지질 과산화물 함량을 보였다. 이는 지질 과산화물 생성에 식물의 폴리페놀 외 당단백질, 단백질 효소, 지방산 성분 등 에 따라 차이가 생긴다는 Niki 등의 보고와 일치하였다(Niki 등, 2005).

\section{튀니지 식물 추출물의 HPLC에 따른 폴리페놀 함량}

지질 과산화물 억제 활성이 높은 식물 추출물 5 종에 함유 된 caffeic acid, quercetin 및 rutin 함량을 확인하기 위하여 HPLC 분석하였으며, 결과를 Table 3과 Fig. 1에 나타냈다. Caffeic acid 함량은 C. villosus L.(5.28 mg/g), P. lentiscus L. $(4.26 \mathrm{mg} / \mathrm{g}), R$. officinalis L.(10.62 mg/g) 및 T. capitatus Hoffmanns. \& $\operatorname{Link}(4.33 \mathrm{mg} / \mathrm{g})$ 로 나타났으며 A. arenaria Link에서는 검출되지 않았다. Quercetin 함량은 A. arenaria $\operatorname{Link}(8.12 \mathrm{mg} / \mathrm{g})$, C. villosus L.(8.25 $\mathrm{mg} / \mathrm{g})$, P. lentiscus L. $(9.29 \mathrm{mg} / \mathrm{g})$, R. officinalis L.(12.17 mg/g) 및 T. capitatus Hoffmanns. \& $\operatorname{Link}(12.70 \mathrm{mg} / \mathrm{g})$ 로 검출되었다. Rutin은 $A$. arenaria $\operatorname{Link}(1.67 \mathrm{mg} / \mathrm{g})$ 에서만 검출되었고, 나머지 4종의 rutin 함량은 검출한계 이하로 나타났다. Quercetin과 caffeic acid 함량이 높은 R. officinalis L.은 11종의 튀니지 식물 중 낮은 항산화 활성 결과를 보였는데, 이는 quercetin과 caffeic acid뿐만 아니라, 식물을 구성하는 수많은 폴리페놀 성분 간 의 상호작용에 의한 것으로 사료된다. 지질 과산화물 억제 효 과는 quercetin과 caffeic acid 성분에 의해 나타난다는 Abdallah 등(2012)의 보고와 일치하였으며, 이에 따른 HepG2 세포에서의 산화 스트레스 억제 효과 및 지질 축적률 억제효 과가 나타날 것으로 판단된다.

Table 3. Flavonoid contents of 5 Tunisian plants extracts

\begin{tabular}{|c|c|c|c|}
\hline \multirow{2}{*}{ Samples } & \multicolumn{3}{|c|}{ Contents (mg/g) } \\
\hline & $\begin{array}{c}\text { Caffeic acid } \\
\left(\mathrm{Rt}^{1)}: 15.417 \mathrm{~min}\right)\end{array}$ & $\begin{array}{l}\text { Quercetin } \\
\text { (Rt: } 4.443 \mathrm{~min})\end{array}$ & $\begin{aligned} & \text { Rutin } \\
\text { (Rt: } & 2.094 \mathrm{~min} \text { ) }\end{aligned}$ \\
\hline Ammophila arenaria Link & $\mathrm{ND}^{2)}$ & $8.12 \pm 0.01^{\mathrm{d}}$ & $1.67 \pm 0.02$ \\
\hline Cistus villosus $\mathrm{L}$. & $5.28 \pm 0.02^{\mathrm{b} 3)}$ & $8.25 \pm 0.01^{\mathrm{d}}$ & ND \\
\hline Pistacia lentiscus L. & $4.26 \pm 0.02^{\mathrm{a}}$ & $8.29 \pm 0.06^{\mathrm{c}}$ & ND \\
\hline Rosmarinus officinalis $\mathrm{L}$. & $10.62 \pm 0.68^{\mathrm{c}}$ & $12.17 \pm 0.12^{\mathrm{b}}$ & ND \\
\hline Thymus capitatus Hoffmanns. \& Link & $4.33 \pm 0.13^{\mathrm{c}}$ & $12.70 \pm 0.20^{\mathrm{a}}$ & ND \\
\hline
\end{tabular}

\footnotetext{
${ }^{1)} \mathrm{Rt}$, retention time.

${ }^{2}$ Non detected.

${ }^{3)}$ All values represent mean \pm SD $(n=3)$. Values with different letters are significantly different by Duncan's multiple range test ( $\mathrm{p}<0.05$ ).
} 

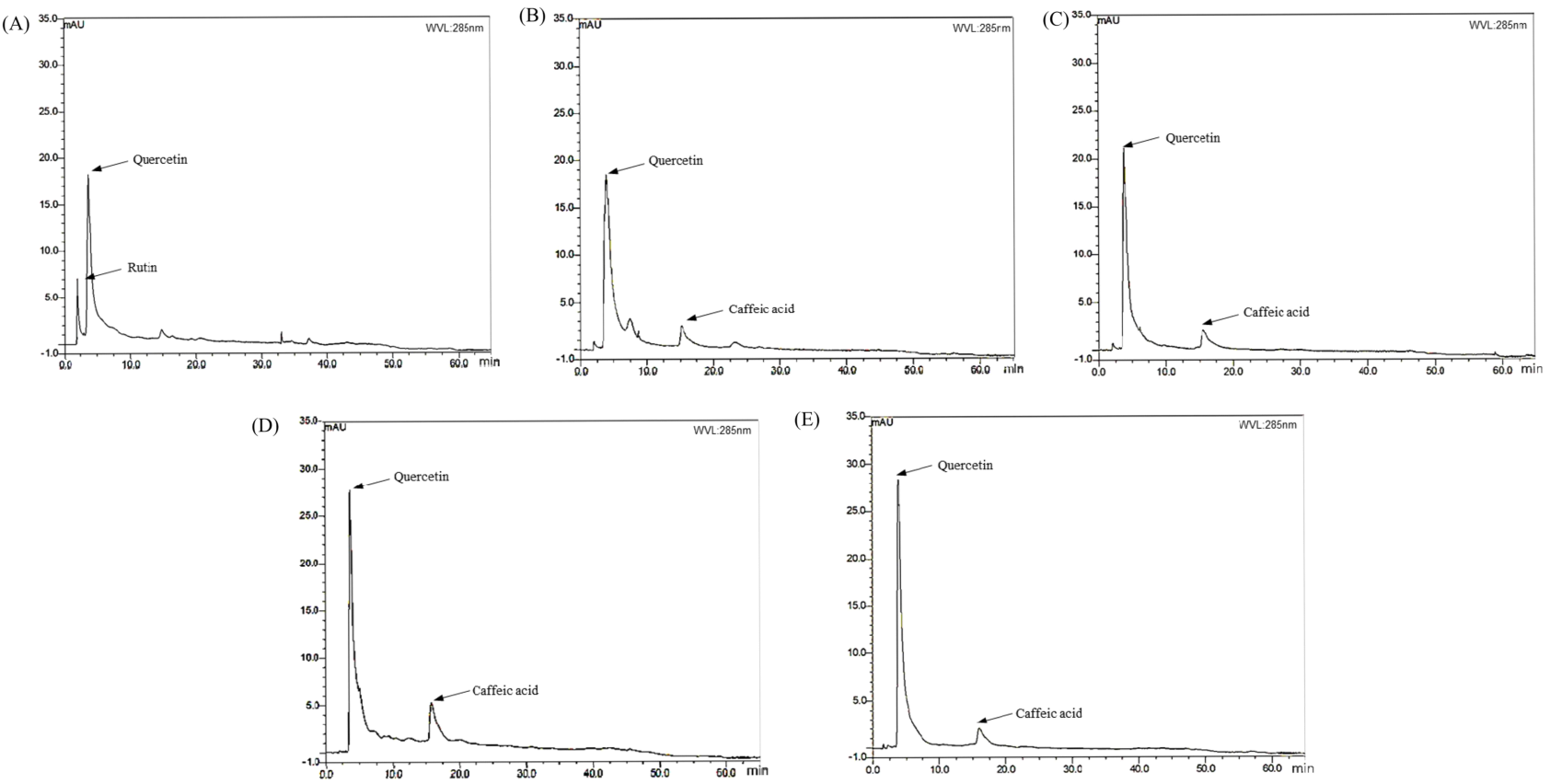

Fig. 1. HPLC analysis of total flavonoids in Tunisian plants extracts.

A, Ammophila arenaria Link; B, Cistus villosus L.; C, Pistacia lentiscus L.; D, Rosmarinus officinalis L.; E, Thymus capitatus Hoffamanns. \& Link were analyzed by HPLC.

Data are expressed as mean \pm SD $(n=3)$ and a different letter indicates a significant difference between means, according to ANOVA with Duncan's multiple range test at $\mathrm{p}<0.05$.

\section{튀니지 식물 추출물의 세포독성 평가}

튀니지 식물 추출물에 의한 $\mathrm{HepG} 2$ 세포의 생존율을 확인 한 결과를 Fig. 2A에 나타냈다. 지질 과산화물 함량 측정을 통해 선별한 튀니지 식물 5종의 HepG2 세포 생존율을 측정 한 결과, 시료를 첨가하지 않은 세포에 비해 A. arenaria Link 는 $0.4 \mathrm{mg} / \mathrm{mL}$ 에서, 나머지 시료는 $0.2 \mathrm{mg} / \mathrm{mL}$ 에서 세포 생존 율이 유의적으로 감소하였다. Milia 등(2020)에 따르면 $P$. lentiscus $\mathrm{L}$.가 primary gingival fibroblasts에서 $0.1 \mathrm{mg} / \mathrm{mL}$ 농 도까지 세포 독성을 보이지 않았으며, 항균 및 항염증 효과를 나타낸다고 보고하였다. 따라서 본 논문에서는 세포 생존율 과 활성을 고려하여 이하 모든 세포 실험에서 $0.1 \mathrm{mg} / \mathrm{mL}$ 농 도의 시료를 사용하였다.

\section{튀니지 식물의 산화스트레스에 대한 HepG2 세포 보호효과}

간세포가 더 이상 지방을 축적할 수 없을 정도로 과도하게 축적되면, 미토콘드리아 내에 유리지방산 수준이 증가하고, 결과적으로 미토콘드리아에서 일어나는 베타-산화가 증가하 면서 과량의 과산화수소 $\left(\mathrm{H}_{2} \mathrm{O}_{2}\right)$ 가 생성된다(Shin 등, 2018). 과산화수소는 세포 내 활성산소 및 지질 과산화물을 증가시 켜 미토콘드리아의 기능 손상 및 간독성으로 세포생존율이 감소된다. 본 연구에서는 튀니지 식물 5종 추출물의 HepG2
세포에서 산화스트레스 보호 효과를 확인하기 위해 0.1 $\mathrm{mg} / \mathrm{mL}$ 의 추출물 및 $200 \mu \mathrm{M}$ 의 $\mathrm{H}_{2} \mathrm{O}_{2}$ 를 24시간 처리하여 확 인하였다(Fig. 2B). $200 \mu \mathrm{M}$ 의 $\mathrm{H}_{2} \mathrm{O}_{2}$ 만 처리한 세포의 경우, $\mathrm{H}_{2} \mathrm{O}_{2}$ 를 처리하지 않은 세포보다 세포 생존율이 $35.38 \%$ 감소 하였다. 반면, 튀니지 식물 5 종 추출물을 함께 처리한 경우 $\mathrm{H}_{2} \mathrm{O}_{2}$ 만 처리한 세포보다 세포 생존률이 A. arenaria Link (36\%), C. villosus L.(31\%), P. lentiscus L.(37\%), $R$. officinalis L.(29\%) 및 T. capitatus Hoffmanns. \& Link(35\%) 가 증가하였다. 양성대조군인 quercetin의 세포 생존율은 $\mathrm{H}_{2} \mathrm{O}_{2}$ 만 처리한 세포보다 $23 \%$ 증가하여 튀니지 식물 5종의 산화스 트레스에 대한 높은 세포보호 효과를 확인하였다. $\mathrm{Hu}$ 등(2015) 에 따르면 R. officinalis L.이 속한 Rosmarinus 종에는 폴리페 놀인 carnosic acid가 다량 존재하며, 이는 siRNA-mediated sirtuin 1 silencing 신호전달 경로 억제를 통해 $\mathrm{H}_{2} \mathrm{O}_{2}$ 로 유도 한 glutathione 및 젖산 탈수소 효소 활성을 감소하여 $\mathrm{H}_{2} \mathrm{O}_{2}$ 로 인한 간세포 보호효과를 지닌다고 보고되었다. 본 논문에서 R. officinalis L.의 산화스트레스 세포보호 효과는 $29 \%$ 로 높 았으며, 폴리페놀 함량이 가장 높았던 P. lentiscus L.의 세포 보호 효과가 가장 높게 나타나 폴리페놀에 의한 산화스트레 스 감소로 HepG2 세포 보호 활성이 나타났음을 확인하였다.

세포질 내에 지방산이 축적되면, 산화과정에서 지질 과산 


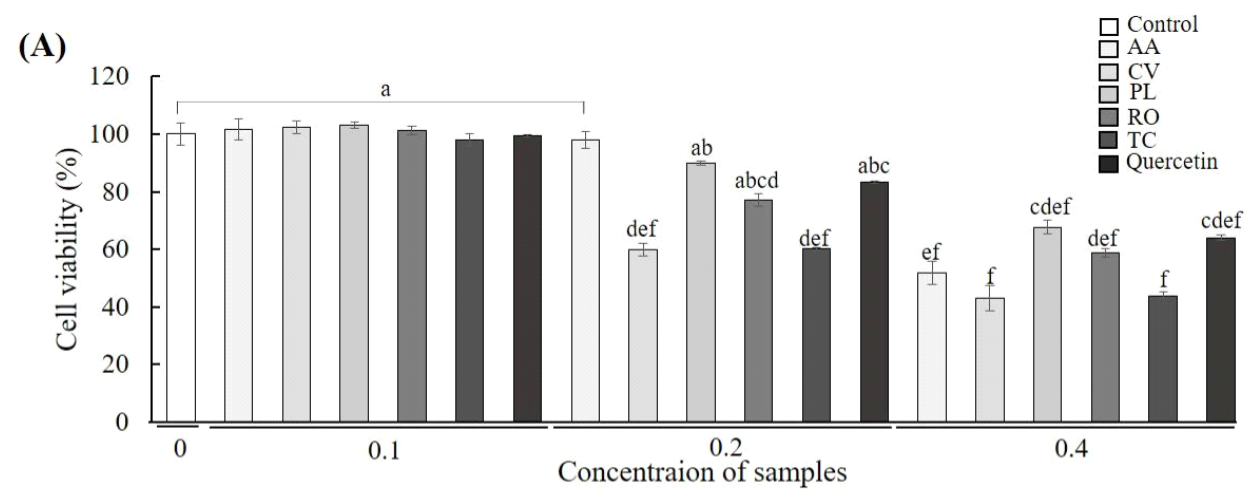

(B)

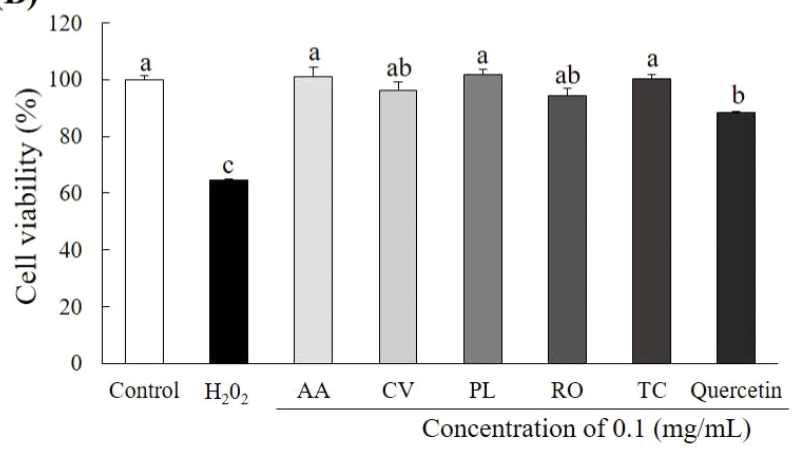

(C)

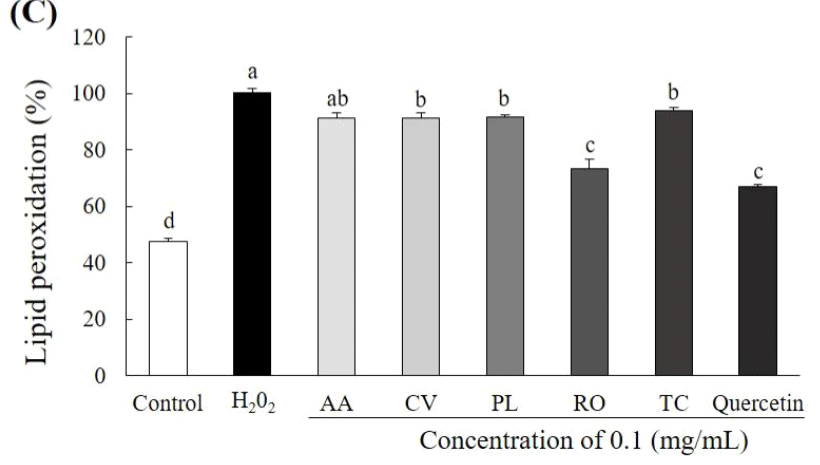

Fig. 2. Cell viability and protective effects of 5 Tunisia plants against $\mathrm{H}_{2} \mathrm{O}_{2}$-induced oxidative stress in HepG2 cells.

Cells were incubated with 100,200 and $400 \mu \mathrm{g} / \mathrm{mL}$ of extracts for $24 \mathrm{~h}$.

$\mathrm{A}$, cell viability of the treatment with extracts were determined in HepG2 cell by MTT assay; B, cell viability; C, lipid peroxidation measured in $\mathrm{H}_{2} \mathrm{O}_{2}$-induced oxidative stress in $\mathrm{HepG} 2$ cell.

AA, Ammophila arenaria Link; CV, Cistus villosus L.; PL, Pistacia lentiscus L.; RO, Rosmarinus officinalis L.; TC, Thymus capitatus Hoffamanns. \& Link.

Data are expressed as mean $\pm \mathrm{SD}(\mathrm{n}=3)$ and a different letter indicates a significant difference between means, according to ANOVA with Duncan's multiple range test at $\mathrm{p}<0.05$.

화물인 malondialdehyde, 4-hydroxyl-2,2-nonenal(HNE) 및 4-hydroxyl-2,3-alkenals(HAKs) 등이 생성된다. 활성산소와 알데히드류는 산화 스트레스를 유발시켜 세포사멸을 유도하 며, 염증성 cytokine 생성을 촉진시켜 염증반응을 유도함으로 써 호중구를 자극시킨다(Vuppalanchi 등, 2011). 지질 과산화 물이 증가하면 간 성상세포(hepatic stellate cells)가 활성화되 고, 콜라겐 합성과 염증반응이 촉진됨으로써 간 섬유화가 유 발된다. 튀니지 식물의 산화적 스트레스로 인한 지질 과산화 물에 대한 억제 효과를 확인한 결과, $\mathrm{HepG} 2$ 세포에 $\mathrm{H}_{2} \mathrm{O}_{2}$ 를 단독 처리한 세포는 $\mathrm{H}_{2} \mathrm{O}_{2}$ 를 처리하지 않은 세포에 비해 지질 과산화물 함량이 $52.53 \%$ 증가하였다. 세포에 튀니지 식물 5종 을 처리한 경우는 $\mathrm{H}_{2} \mathrm{O}_{2}$ 처리한 세포와 비교하여 A. arenaria Link(8.73\%), C. villosus L.(8.62\%), P. lentiscus L.(8.35\%), R. officinalis L.(26.57\%) 및 T. capitatus Hoffmanns. \& $\operatorname{Link}(6.17 \%)$ 가 감소하여 유의한 지질 과산화물 생성 억제 효 과를 보였다(Fig. 2C). 양성대조군인 quercetin의 지질 과산화 물 억제율은 $33.09 \%$ 를 보여 추출물 5 종보다 높은 활성을 확
인하였다. 한편, 본 연구에서 HPLC 분석으로 quercetin 및 caffeic acid 함량이 가장 높았던 R. officinalis L.의 지질 과산 화물 억제 활성이 가장 높아 지질 과산화물 억제 효과가 quercetin 및 caffeic acid 성분에 의한 것이라고 사료된다. 이 를 통해 간의 중성지방 함량 감소로 인한 산화스트레스 유발 억제로 간세포 보호효과를 나타낸다는 Morita 등(2012)의 보 고를 검증하였다.

\section{튀니지 식물 추출물의 HepG2 세포에서 지질축적 및 중성지방 감소효과}

튀니지 식물의 지질축적 억제 활성을 측정하기 위해 $\mathrm{HepG} 2$ 세포에 $\mathrm{OA}$ 를 이용하여 지방 생성을 유도 후 ORO 염색법으로 평가하였다. 분화 완료된 $\mathrm{HepG} 2$ 세포를 $\mathrm{ORO}$ 로 염색하고, 현미경을 통해 관찰 후 정량하였다(Fig. $3 \mathrm{~A}, \mathrm{~B}$ ). 그 결과, $\mathrm{OA}$ 만 단독 처리한 세포는 $\mathrm{OA}$ 를 처리하지 않은 세포에 비해 지방구 형성이 많이 유발된 것을 관찰하였으며, 이를 정 량한 결과, 지질 축적률이 2.79 배 증가하였다( $<0.05)$. 튀니지 
(A)

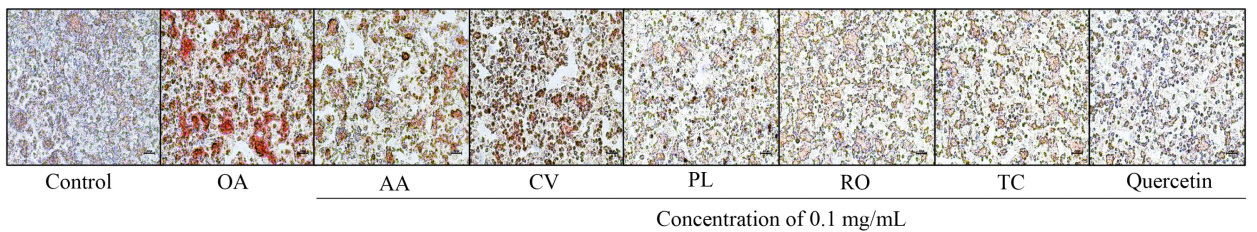

(B)

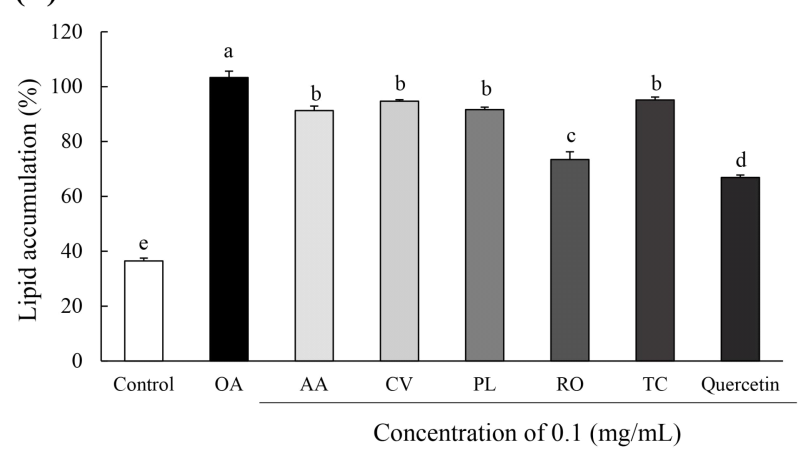

(C)

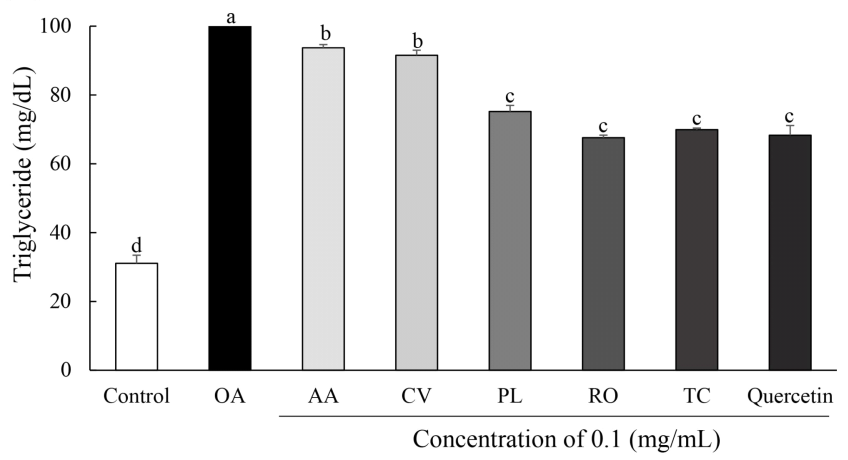

Fig. 3. Effect of 5 Tunisian plants extracts on lipid accumulation oleic acid induced in HepG2 cells.

(A) HepG2 cells were stained with Oil Red $\mathrm{O}$ and observed under the microscope and (B) quantified lipid accumulation and (C) measured triglyceride content. Data are expressed as means $\pm \mathrm{SD}(\mathrm{n}=3)$ and a different letter indicates a significant difference between means, according to ANOVA with Duncan's multiple range test at $\mathrm{p}<0.05$. range test. OA, Oleic acid; AA, Ammophila arenaria Link; CV, Cistus villosus L.; PL, Pistacia lentiscus L.; RO, Rosmarinus officinalis L.; TC, Thymus capitatus Hoffamanns. \& Link.

식물을 처리한 세포는 각각 A. arenaria $\operatorname{Link}(9.62 \%), C$. villosus L.(6.13\%), P. lentiscus L.(8.14\%), $R$. officinalis L.(27.08\%), T. capitatus Hoffmanns. \& Link(5.41\%)의 지질 축적률 억제 효과를 확인하였다. 양성대조군으로 쓰인 quercetin의 지질 축적 억제 효과는 $33.36 \%$ 로 나타났다. 튀니 지 식물 5 종의 지질 축적률 $\mathrm{OA}$ 만 처리한 세포에 비해 모두 유의적인 감소를 보여 효과적인 지질 축적률 억제 효과를 확 인하였다. Borras-Linares 등(2014)에 따르면 HPLC-ESIQTOF-MS 결과, R. officinalis L.의 주성분이 genkwanin, cirsimaritin, homoplantaginin 및 triterpenes 계열의 플라보노 이드이며, $\mathrm{Di}$ 등(2018)에 따르면 triterpenes이 지방산 합성과 지방산 산화 과정을 조절하여 $\mathrm{HepG} 2$ 세포의 지질 축적률 억 제 효과를 지닌다고 보고되었다. 따라서 튀니지 식물 5종 중 플라보노이드 함량이 가장 높았던 R. officinalis L.의 지질 축 적 억제율이 가장 낮은 결과를 통해 플라보노이드 성분에 의 한 지질 축적률 억제 효과를 확인하였다.

간에서 적당한 중성지방 함량은 혈장에서 비에스테르화 된 지방산의 흡수와 지방산 합성 및 지방간 산화 과정 사이의 정확한 균형에 기인한다. 하지만 과도한 중성지방의 축적은 지방간으로 인한 간기능 저하, 비만, 고지혈증, 간경화 및 간 암 등 다양한 대사 질환의 원인이 된다(Kawano 등, 2013). 따라서 본 연구에서는 $\mathrm{HepG} 2$ 에 $\mathrm{OA}$ 를 처리하여 지방 생성
을 유도 후 튀니지 식물의 중성 지방 함량을 측정하여 Fig. $3 \mathrm{C}$ 에 제시하였다. $\mathrm{OA}$ 를 처리하지 않은 $\mathrm{HepG} 2$ 세포의 중성 지방 함량은 $31.07 \mathrm{mg} / \mathrm{dL}$ 로 나타났으며, $\mathrm{OA}$ 만 처리한 세포의 중성 지방 함량은 $103.33 \mathrm{mg} / \mathrm{dL}$ 로 나타나, 중성 지방 생성이 3.33 배 증가됨을 확인하였다 $(\mathrm{p}<0.05)$. 튀니지식물 5종을 처리 한 세포의 중성지방 함량은 A. arenaria $\operatorname{Link}(93.72 \mathrm{mg} / \mathrm{dL})$, C. villosus L.(91.54 mg/dL), P. lentiscus L.(75.19 mg/dL), R. officinalis L.(67.59 mg/dL), T. capitatus Hoffmanns. \& $\operatorname{Link}(69.93 \mathrm{mg} / \mathrm{dL})$ 로 $\mathrm{OA}$ 만 처리한 세포와 비교하여 평균 $25.62 \mathrm{mg} / \mathrm{dL}$ 억제 효과를 나타냈다. 양성대조군인 quercetin 의 중성 지방 함량은 $68.31 \mathrm{mg} / \mathrm{dL}$ 로 $R$. officinalis L. 및 $T$. capitatus Hoffmanns. \& Link종과 유의적인 차이를 보이지 않아 튀니지 식물의 간세포에서 우수한 중성 지방 억제 활성 을 확인하였다. T. capitatus Hoffmanns. \& Link가 속한 Thymus종 중 T. longicaulis, T. praecox, T. pulegioides, T. serpyllum, T. striatus 및 T. vulgaris 6 종의 $0.1 \mathrm{mg} / \mathrm{mL}$ 농도 에서 지질 과산화물 억제 효과가 모두 $50 \%$ 이상으로 나타났 으며, 이에 따른 중성지방 함량 억제가 보고되었다(Afonso 등, 2018; Kindl 등, 2015). 본 논문에서 튀니지 식물 11종 중 지질 과산화물 함량이 가장 낮았고, HPLC 분석 결과 quercetin 함량이 높았던 순서대로 중성지방 함량이 가장 낮 게 나타나 지질 과산화물 억제에 따른 간세포에서의 중성지 
방 함량 억제 효능이 나타났다고 판단된다.

이상의 결과를 통해, 튀니지 식물 11종의 총 폴리페놀 및 플라보노이드 함량에 의한 항산화 활성을 확인하였다. 지질 과산화물 함량 억제 활성을 통해 선별한 5 종의 $\mathrm{HepG2}$ 세포 에서 지질 축적률 억제 효과 및 산화 스트레스 보호 효과를 확인하였다. 이를 활용하였을 시 간세포 보호 효과를 가질 것 으로 사료된다. 향후 튀니지 식물을 이용하기 위해 원료의 표 준화, 기능성 및 안전성에 대한 추가 연구가 필요하다고 판단 된다.

\section{요 약}

본 연구는 튀니지 식물 추출물 11종의 생리 효능을 체계적 으로 밝히기 위한 기초 자료를 얻고자 $\mathrm{HepG} 2$ 세포에서 식물 11 종의 산화스트레스 및 지질 축적률 억제 효과를 검증하였 다. 튀니지 식물 중 총폴리페놀 함량 및 총플라보노이드 함량 은 각각 P. lentiscus L.과 N. glauca Graham이 가장 높았다. 튀니지식물 11종의 DPPH, ABTS, FRAP 및 ORAC를 통한 우수한 항산화 활성을 확인하였다. 지질 과산화물 함량 억제 효과는 R. officinalis L.과 T. capitatus Hoffmanns. \& Link에 서 가장 높았으며 quercetin 및 caffeic acid 성분에 의한 것임 을 확인하였다. 11 종 중 지질과산화물 함량 억제 효과가 높은 상위 5 종의 $\mathrm{HepG} 2$ 세포에서 $\mathrm{ORO}$ 염색법 및 중성 지방 함량 을 측정한 결과, $R$. officinalis L.에서 oleic acid만 처리한 세 포에 비해 $25 \%$ 이상의 지질 축적률 및 중성지방 함량 억제 효과를 보였다. 이상의 결과로부터 본 논문이 튀니지 식물 11 종의 생리활성물질, 항산화 활성 및 지질 축적 억제 활성을 검토하는 기초 자료로 활용될 수 있을 것이라 사료된다.

\section{감사의 글}

본 연구는 2021년도 덕성여자대학교 교내연구비 지원에 의해 수행되었으며 감사드립니다. 본 연구는 해외생물소재센 터(IBMRC; International Biological Material Research Center, Daejeon, Korea)로부터 식물 추출물을 분양 받아 수 행되었으며, 이에 감사드립니다.

\section{Conflict of interests}

The authors declare no potential conflict of interest.

\section{ORCID}

SukJin Kim

https://orcid.org/0000-0002-4906-3817
Gun-Hee Kim https://orcid.org/0000-0001-8196-7149

\section{References}

Abdallah FB, Fetoui H, Fakhfakh F, Keskes L. Caffeic acid and quercetin protect erythrocytes against the oxidative stress and the genotoxic effects of lambda-cyhalothrin in vitro. Hum Exp Toxicol, 31, 92-100 (2012)

Afonso AF, Pereira OR, Valega M, Silva AMS, Cardoso SM. Metabolites and biological activities of Thymus zygis, Thymus pulegioides, and Thymus fragrantissimus grown under organic cultivation. Molecules, 23, 1514 (2018)

Ahn EM, Kang HJ, Kim Y, Choe JS, Kang MS. Effects of ethanol extracts from commonly consumed vegetables in Korea on differentiation and secretion of MCP-1 and adiponectin in 3T3-L1 adipocytes and lipid accumulation in HepG2 hepatocytes. J East Asian Soc Dietary Life, 25, 99-110 (2015)

Alamri ZZ. The role of liver in metabolism: An updated review with physiological emphasis. Int $\mathrm{J}$ Basic Clin Pharmacol, 7, 2271-2276 (2018)

Amensour M, Sendra E, Abrini J, Bouhdid S, Perez-Alvarez JA, Fernandez-Lopez J. Total phenolic content and antioxidant activity of myrtle (Myrtus communis) extracts. Nat Prod Commun, 4, 819-824 (2009)

Balachander GJ, Subramanian S, Ilango K. Rosmarinic acid attenuates hepatic steatosis by modulating ER stress and autophagy in oleic acid-induced HepG2 cells. RSC Adv, 8, 26656-26663 (2018)

Bayle GK. Ecological and social impacts of eucalyptus tree plantation on the environment. J Biodivers Conserv Bioresour Manag, 5, 93-104 (2019)

Bianchin M, Pereira D, Almeida JF, Moura C, Pinheiro RS, Heldt LFS, Haminiuk CWI, Carpes ST. Antioxidant properties of lyophilized rosemary and sage extracts and its effect to prevent lipid oxidation in poultry pate. Molecules, 25, 5160 (2020)

Brieger K, Schiavone S, Miller FJ, Krause KH. Reactive oxygen species: From health to disease. Swiss Med Wkly. 142, w13659 (2012)

Cory H, Passarelli S, Szeto J, Tamez M, Mattei J. The role of polyphenols in human health and food systems: A mini-review. Front Nutr, 5, 87 (2018) 
Dall'Acqua S, Cervellati R, Speroni E, Costa S, Guerra MC, Stella L, Greco E, Innocenti G. Phytochemical composition and antioxidant activity of Laurus nobilis L. leaf infusion. J Med Food, 12, 869-876 (2009)

Franco AM, Tocci N, Guella G, Dell'Agli M, Sangiovanni E, Perenzoni D, Vrhovsek U, Mattivi F, Manca G. Myrtle seeds (Myrtus communis L.) as a rich source of the bioactive ellagitannins oenothein B and eugeniflorin $\mathrm{D}_{2}$. ACS Omega, 4, 15966-15974 (2019)

Gamoun M, Belgacem AO, Louhaichi M. Diversity of desert rangelands of Tunisia. Plant Divers, 40, 217-225 (2018)

Guan YS, He Q. Plants consumption and liver health. Evid-Based Complementary Altern Med, 2015, 824185 (2015)

Gurnani N, Gupta M, Mehta D, Mehta BK. Chemical composition, total phenolic and flavonoid contents, and in vitro antimicrobial and antioxidant activities of crude extracts from red chilli seeds (Capsicum frutescens L.). J Taibah Univ Sci, 10, 462-470 (2016)

Hassine DB, Abderrabba M, Yvon Y, Lebrihi A, Mathieu F, Couderc F, Bouajila J. Chemical composition and in vitro evaluation of the antioxidant and antimicrobial activities of Eucalyptus gillii essential oil and extracts. Molecules, 17, 9540-9558 (2012)

Hu Y, Zhang N, Fan Q, Lin M, Zhang C, Fan G, Zhai X, Zhang F, Chen Z, Yao J. Protective efficacy of carnosic acid against hydrogen peroxide induced oxidative injury in HepG2 cells through the SIRT1 pathway. Can J Physiol Pharmacol, 93, 625-631 (2015)

Iauk L, Acquaviva R, Mastrojeni S, Amodeo A, Pugliese M, Ragusa M, Loizzo MR, Menichini F, Tundis R. Antibacterial, antioxidant and hypoglycaemic effects of Thymus capitatus (L.) Hoffmanns. et Link leaves' fractions. J Enzyme Inhib Med Chem, 30, 360-365 (2015)

Kawano Y, Cohen DE. Mechanisms of hepatic triglyceride accumulation in non-alcoholic fatty liver disease. J Gastroenterology, 48, 431-441 (2013)

Kindl M, Blazekovic B, Bucar F, Vladimir-Knezevic S. Antioxidant and anticholinesterase potential of six Thymus species. Evid-Based Complementary Altern Med, 2015, 403950 (2015)

Kumar P, Sharma S, Khanna M, Raj HG. Effect of quercetin on lipid peroxidation and changes in lung morphology in experimental influenza virus infection. Int J Exp Path,
84, 127-133 (2003)

Lam PL, Wong RSM, Lam KH, Hung LK, Wong MM, Yung LH, Ho YW, Wong WY, Hau DKP, Gambari R, Chui $\mathrm{CH}$. The role of reactive oxygen species in the biological activity of antimicrobial agents: An updated mini review. Chem Biol Interact, 320, 109023 (2020)

Lewoyehu M, Amare M. Comparative evaluation of analytical methods for determining the antioxidant activities of honey: A review. Cog Food Agric, 5, 1685059 (2019)

Li R, Jia Z, Trush MA. Defining ROS in biology and medicine. React Oxyg Species (Apex), 1, 9-21 (2016)

Mahmoud MAOM, Hamza S. Genetic diversity in local barley accessions collected from different geographical regions of Tunisia. Plant Genet Resour, 7, 169-176 (2009)

Milia E, Usai M, Szotakova B, Elstnerova M, Kralova V, D'hallewin G, Spissu Y, Barberis A, Marchetti M, Bortone A, Campanella V, Mastandrea G, Langhansova L, Eick S. The pharmaceutical ability of Pistacia lentiscus L. leaves essential oil against periodontal bacteria and candida sp. and its anti-inflammatory potential. Antibiotics, 9, 281 (2020)

Morita M, Ishida N, Uchiyama K, Yamaguchi K, Itoh Y, Shichiri M, Yoshida Y, Hagihara Y, Naito Y, Yoshikawa T, Niki E. Fatty liver induced by free radicals and lipid peroxidation. Free Radic Res, 46, 758-765 (2012)

Mulas M, Mulas G. Cultivar selection from rosemary (Rosmarinus officinalis L.) spontaneous populations in the mediterranean area. Acta Hortic, 676, 127-133 (2005)

Niki E, Yoshida Y, Saito Y, Noguchi N. Lipid peroxidation: Mechanisms, inhibition, and biological effects. Biochem Biophys Res Commun, 338, 668-676 (2005)

Panche AN, Diwan AD, Chandra SR. Flavonoids: An overview. J Nutr Sci, 5, e47 (2016)

Park JS, Yoo BW, Cho YJ, Oh JE, Hong SH, Cho CY. The factors related to the incidence of non-alcoholic-fattyliver-disease (NAFLD) in obese patients. Soonchunhyang Med Sci, 15, 75-82 (2009)

Remila S, Atmani-Kilani D, Delemasure S, Connat JL, Azib L, Richard T, Atmani D. Antioxidant, cytoprotective, anti-inflammatory and anticancer activities of Pistacia lentiscus (Anacardiaceae) leaf and fruit extracts. Eur J Integr Med, 7, 274-286 (2015)

Rodriguez-Echeverria S, Freitas H, van der Putten WH. 
Genetic diversity and differentiation of Ammophila arenaria (L.) link as revealed by ISSR markers. J Coastal Res, 24, 122-126 (2008)

Romani A, Pinelli P, Mulinacci N, Vincieri FF, Tattini M. Identification and quantitation of polyphenols in leaves of Myrtus communis L. Chromatographia, 49, 17-20, (1999)

Sayah K, Marmouzi I, Mrabti HN, Cherrah Y, Faouzi MEA. Antioxidant activity and inhibitory potential of Cistus salviifolius (L.) and Cistus monspeliensis (L.) aerial parts extracts against key enzymes linked to hyperglycemia. BioMed Res Int, 2017, 2789482 (2017)

Shin SK, Cho HW, Song SE, Song DK. Catalase and nonalcoholic fatty liver disease. Pflugers Arch-Eur J Physiol, 470, 1721-1737 (2018)

Stefan PN, Haring HU, Cusi K. Non-alcoholic fatty liver disease: Causes, diagnosis, cardiometabolic consequences, and treatment strategies. Lancet Diabetes Endocrinol, 7, 313-324 (2019)

Stratil P, Klejdus B, Kuban V. Determination of total content of phenolic compounds and their antioxidant activity in vegetables evaluation of spectrophotometric methods. J Agric Food Chem, 54, 607-616 (2006)

Tabana YM, Dahham SS, Hassan LEA, Al-Mansoub MA, Taleb-Agha M, Majid AMSA. In vitro anti-metastatic and antioxidant activity of Nicotiana glauca fraction against breast cancer cells. Adv Biol Res, 9, 95-102 (2015)
Tungmunnithum D, Thongboonyou A, Pholboon A, Yangsabai A. Flavonoids and other phenolic compounds from medicinal plants for pharmaceutical and medical aspects: An overview. Medicines (Basel), 5, 93 (2018)

Vergara D, Casadei-Gardini A, Giudetti AM. Oxidative molecular mechanisms underlying liver diseases: From systems biology to the personalized medicine. Oxid Med Cell Longevity, 2019, 7864316 (2019)

Vuppalanchi R, Ghabril M, Chalasani N, Juluri R, Bell LN, Kamendulis L, Klaunig JE, Saxena R, Agarwal D, Johnson MS. Oxidative stress in chronic liver disease: Relationship between peripheral and hepatic measurements. Am J Med Sci, 342, 314-317 (2011)

Wahyono A, Dewi AC, Ktavia S, Jamilah S, Kang WW. Antioxidant activity and total phenolic contents of bread enriched with pumpkin flour. IOP Conf Ser Earth Environ Sci, 411, 012049 (2020)

Walker JM. The bicinchoninic acid (BCA) assay for protein quantitation. Methods Mol Biol, 32, 5-8 (1994)

You H, Jin H, Khaldi A, Kwak M, Lee T, Khaine I, Jang J, Lee H, Kim I, Ahn T, Song J, Song Y, Khorchani A, Stiti B, Woo S. Plant diversity in different bioclimatic zones in Tunisia. J Asia Pac Biodivers, 9, 56-62 (2016)

Youn Y, Kim HY, Park HM, Lee SH, Park JR, Hong SG Kim YG. Protective effects of mulberry (Morus alba) sugar extracts on hydrogen peroxide-induced oxidative stress in HepG2 cell. Korean J Food Preserv, 22, 751-757 (2015) 